TURIZAM

Volume 18 , Issue 3

140-153 (2014)

\title{
Tuzla Canton Tourism Offer - Attitudes of Employees in the Tourism Sector
}

\author{
Edin Jahić, Aleksandra Dragin, Tamara Jovanović* \\ Received: November 2013 | Accepted: February 2014
}

\begin{abstract}
Tuzla Canton (TC) has experienced a certain economic transformation and gradually started turning from an industrial region into a region of tertiary and quaternary activities, also notable in the strategic documents of the Canton. The present research was conducted during the years 2012 and 2013 with the aim of determining the attitudes of employees in the tourism sector of TC regarding the condition, i.e. the prospects of TC tourism. In July of 2012, using a structured questionnaire, persons employed in travel agencies and TC hotels were surveyed in relation to the following issues: what is, in their own opinion, the determining factor for a tourist in choosing a tour package in TC as a destination; how would they assess the tourist's motives for choosing TC as a destination; how would they characterize (assess) the value factors of the TC tourist offer. The conducted research indicates that employees in the tourism industry have formed perceptions of TC as a tourist destination: it is a destination where tourists feel pleasant and happy to stay at; it has outstanding natural attractions, a welcoming environment and solid accommodation and catering potentials. However, elements that need improving and further development are highlighted as well. Methods used for collecting, processing and analyzing data are: historical, descriptive, comparative. Frequency analysis was conducted using the SPSS statistical program (version 20). The research results can help the tourist destination management, in this case TC, but also all segments of the tourism industry of TC, improve their offer and communication with a potential tourism market.
\end{abstract}

Key words: Tuzla Canton, tourist destination, attitudes of employees

\section{Introduction}

Over the last fifty years the Canton of Tuzla (TC) has been experiencing a reconstruction in regards to economy, i.e. it has gradually turned from an industrial region into a region of tertiary and quaternary activities, where tourism has managed to impose itself. More specifically, after the trade sector, tourism (including services) registered the fastest and biggest postwar increase in the number of registered businesses and workers. This development is

\footnotetext{
* University of Novi Sad, Faculty of Sciences, Department of Geography, Tourism and Hotel Management, Trg D.
} Obradovića 3, 21000 Novi Sad, Serbia, Corresponding author: edinjahic75@gmail.com 
based on the evaluation of natural and artificial resources of the Canton: preserved flora and fauna, thermal and mineral resources, natural and anthropogenic lakes (e.g. Lake Modrac in Lukavac or the salt lakes in Tuzla, which are the only lakes of that kind in Europe), together with the rich cultural and historical heritage.

That tourism represents a very serious development opportunity for TC is indicated by the fact that the Regional Economic Development Strategy is identified as one of four strategic goals, while health tourism has been identified as one of four strategic orientations for the region (Spatial plan for the area of Tuzla Canton from 2005 to 2O25, 2008:279).

It was also stressed that although TC tourism currently represents a very dynamic economic sector, it too is faced with many problems such as:

- the lack of or unclear infrastructure in some parts of TC;

- low and insufficient promotion;

- lack of partnership or joint appearance on the market;

- weak and insufficient promotion;

- lack of partnership or joint appearance on the market;

- lack of a strong sector for help/additional services;

- insufficient training of human resources;

- complex and costly procedures for private sector development in this area, etc. (Hodzic, 2005:9).

If the quality of tourism infrastructure, the quality of services and tourism products and the promotion of tourism were improved, the development of tourism would be at a much higher level than it is now.

This is why the aim of the research is to study the attitudes of employees of travel agencies and accommodation establishments (primarily hotels - the most representative accommodation capacities). As service providers, they are in direct contact with consumers - tourists, together with a number of primary and secondary stakeholders (local residents, business entities, the country). Therefore, it is clear that this is a pattern that can respond to specific questions regarding the adequacy of the offer and give necessary directions for the development of TC tourism.

\section{Methodology}

Methods used for data collecting, processing and analysis are: historical, descriptive, comparative, case study, survey (SPSS version 2O).

The starting point of the research is based on the analysis of the state of tourism and the material base of tourism, expressed through a registered tourist traffic and accommodation capacities.

Then follows the analysis of the strategic documents through which the attitudes of cantonal authorities in terms of tourism are also explored.

Finally, a survey among employees of travel agencies and TC hotels is conducted. The survey is based on a questionnaire used for exploring the Serbian tourism market during the drafting of the Tourism Strategy of RS (2005, 2006). The five-point Likert scale was used.

A survey on the attitudes of employees in accommodation establishments, as providers of tourist services, regarding the further development of TC tourism was conducted during July of 2OI2, since such establishments represent one of the key segments for creating tour- 
ism development. There are 72 such establishments in TC. During the survey, eight accommodation establishments (II\%) were sampled so as to obtain a more representative picture of the state of tourism in Tuzla Canton.

Survey also investigating the opinion of those employed in travel agencies, as creators of the content of travel arrangements and the ones that place products on the market, about the further development of tourism in Tuzla Canton was conducted during July of 2OI2. There are I8 travel agencies operating in Tuzla Canton and the survey was to cover $20 \%$ of this capacity. In the course of the research a sample of five travel agencies $(27.8 \%)$ was taken in order to obtain a more representative picture of the state of tourism in Tuzla Canton.

The responses used for analysis were divided into several thematic unities. The first one includes socio-demographic characteristics of respondents. The second unity includes respondents attitudes towards tourism in TC. Descriptive statistics was used to present that results - SPSS software.

The research is a part of the doctoral dissertation of Edin Jahić.

\section{Results}

\section{Material Base of Tourism and Tourist Traffic}

In the second half of the $2 \mathrm{O}^{\text {th }}$ and in the first decade of the $2 \mathrm{I}^{\text {st }}$ century, Tuzla Canton (TC) suffered major structural changes in regards to economy, but in many other segments as well. From a typical mining and industrial region it has gradually transformed into a region of tertiary and quaternary activities. The tertiary and quaternary activities today assume pri-

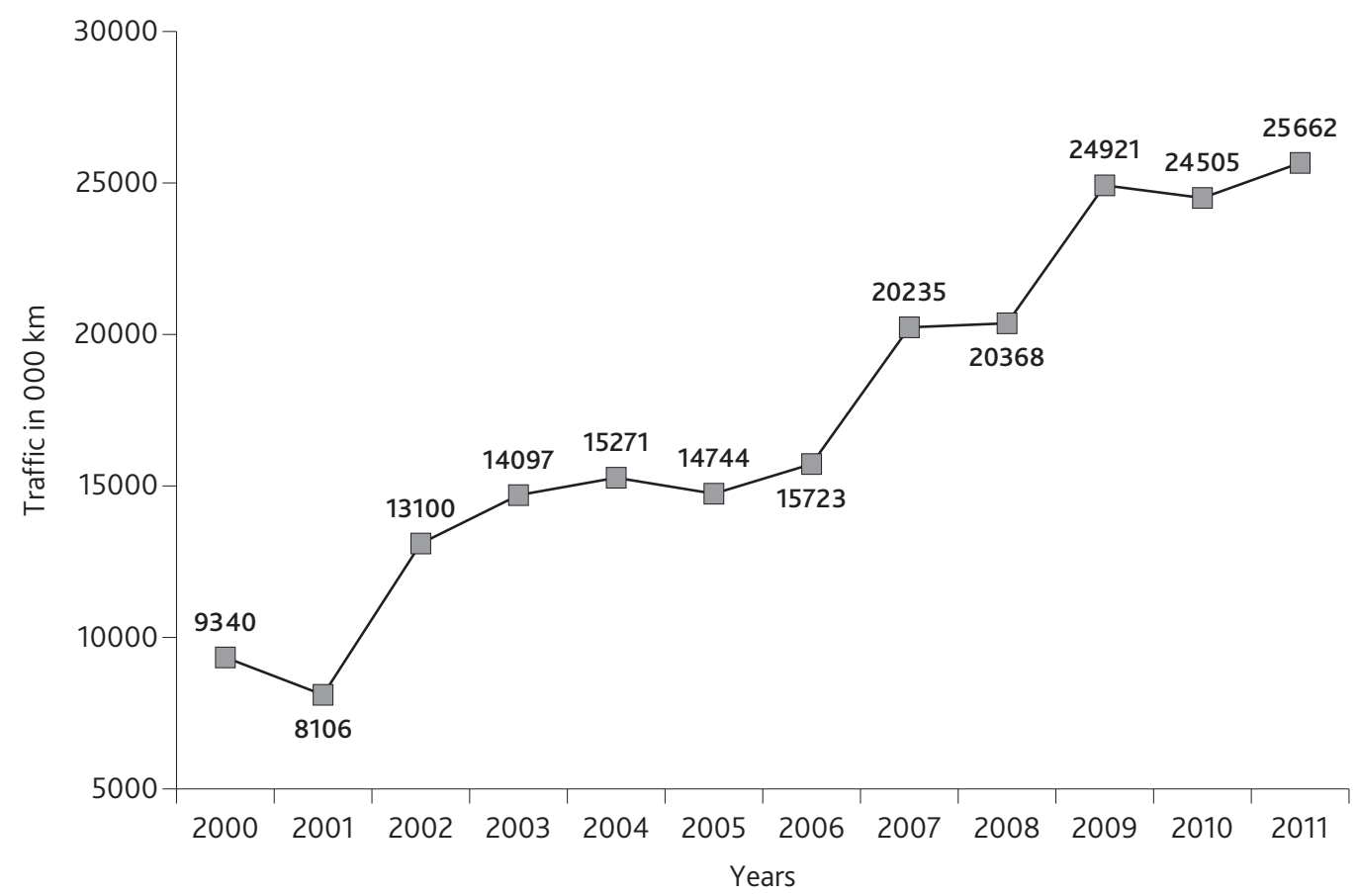

Figure 1: Traffic in the hospitality industry in Tuzla Canton from 2000 to 20011

Source: Ministry of Trade, Tourism and Transport of Tuzla Canton, FBS, 2012. 
Table 1. The number of tourists arrivals and overnight stays in Tuzla Canton from 2000 to 2011

\begin{tabular}{|c|c|c|c|c|c|c|c|c|c|c|c|c|}
\hline Year & 2000 & 2001 & 2002 & 2003 & 2004 & 2005 & 2006 & 2007 & 2008 & 2009 & 2010 & 2011 \\
\hline \multicolumn{13}{|c|}{ Tourists arrivals } \\
\hline Domestic & 21306 & 17801 & 20933 & 21880 & 21377 & 18274 & 18217 & 22855 & 23946 & 20809 & 21425 & 12724 \\
\hline Foreign & 10008 & 8460 & 10263 & 14643 & 18459 & 19205 & 16672 & 12452 & 12460 & 13873 & 12422 & 11273 \\
\hline Total & 31314 & 26261 & 31196 & 36523 & 39836 & 37479 & 34889 & 35307 & 36406 & 34682 & 33874 & 23997 \\
\hline \multicolumn{13}{|c|}{ Overnight stays } \\
\hline Domestic & 41556 & 36001 & 39518 & 39247 & 35141 & 33638 & 33062 & 36272 & 40611 & 25972 & 27128 & 18008 \\
\hline Foreign & 19512 & 15822 & 18319 & 24949 & 29086 & 30302 & 26023 & 29296 & 29104 & 29266 & 24170 & 22420 \\
\hline Total & 61068 & 51823 & 57837 & 64196 & 64227 & 63940 & 59085 & 65568 & 69715 & 55238 & 51298 & 40428 \\
\hline
\end{tabular}

Source: Ministry of Trade, Tourism and Transport of Tuzla Canton, FBS, 2012.

macy in the economic structure of TC. These changes occurred over the last 50 years and were the result of many factors (Economy of B\&H, I988:5). After the trade sector, tourism (including services) registered the fastest and largest postwar increase in the number of registered businesses and workers (Ministry of Trade, Tourism and Transport of Tuzla Canton, 2OI2). When analyzing the period from the year 2000 to 2OII, it is noticeable that the turnover in the hospitality industry has experienced a constant growth and been increased from 9,340,000 to 25,662,000 KM (Chart I).

The situation with tourist traffic, based on accommodation establishments, is somewhat different. The number of tourist arrivals in the year 2000 amounted to 3I,3I4, while the number of overnight stays was 6I,068. This is followed by oscillations in terms of the number of arrivals and overnight stays on an annual level (of both domestic and foreign tourists), whereby maximums, in annual terms, do not overlap (Table I).

In the year 2OII there has been a decrease in tourist traffic in comparison to the previous year: the number of tourist arrivals decreased by $21.76 \%$, the number of overnight stays by $20.67 \%$, the number of domestic tourist arrivals by $30.07 \%$, the number of foreign tourist arrivals by $9.69 \%$, the number of domestic tourists by $32.8 \%$ and, finally, the number of foreign tourists by $7.20 \%$. These indicators are certainly unfavorable for the development of tourism and the overall TC economy. However, when the cumulative period since 2000 to 2OII is observed, it can be seen that, in this period, in TC, there have been 4OI,737 registered tourist arrivals with 663,995 overnight stays (FBS, 2OI2). On the other hand, data regarding the number of tourists and the number of overnight stays for Bosnia and Herzegovina exists only from the year 2005 onward as the Agency for Statistics of Bosnia and Herzegovina is only in disposition of this data. The number of tourist arrivals to B\&H in 2005 was 434,OOO, while in $2 \mathrm{OII}$ there have been 686,000 registered arrivals. Cumulatively, for the period from 2005 to 2OII, this amounts to 4,042,000 tourist arrivals. The number of overnight stays in 2005 totaled I,OI8,OOO, while in 2OII it amounted to I,054,OOO overnight stays, and cumulatively for the period from 2005 to $2 \mathrm{OII}$ to 9,II8, OOO overnight stays (FBS, 2OI2).

The largest number of foreign tourist arrivals in TC area was from countries of its immediate surroundings (Croatia, Slovenia and Serbia), while, in regards to other European countries, the largest number of arriving tourists were from Italy, Austria and Germany (ASBiH, 2OI2).

According to the type of accommodation establishments, in the area of TC most of them are establishments such as motels (I6), hotels (I3) and rooms for rent (I6), then facilities located at the lake Modrac presented as a "rural household" (I6) and pensions (9). The pres- 
ence of inns with beds (2), lodgings (I) and camps (I) is insignificant (Ministry of Trade, Tourism and Transport Tuzla Canton, 2OI2).

From a total of I4 registered hotels in the area of TC only one is categorized as a four-star hotel $\left({ }^{* * * *}\right)$, eight of them as a three-star $\left(^{* * *}\right)$, one hotel as a two-star $\left({ }^{* *}\right)$, two Hotels with one star $\left(^{*}\right)$. Furthermore, one hotel, the hotel "Muška voda" in Kladanj which is undergoing reconstruction, is not ranked, and one hotel is still under construction, the Hotel "Bristol" (Ministry of Trade, tourism and Transport Tuzla Canton, 2OI2).

The average length of tourists' stay in Tuzla Canton in 2OII was I,68 days. This points to an insufficient utilization of tourism potential of Tuzla Canton, as well to problems of insufficient interconnection among accommodation establishments, travel agencies and the Tourist Communities of this Canton. The length of stay of tourists is longest in the municipality of Gradacac with the average length at around IO days, while in other municipalities this is not nearly the case. Since tourists in this municipality mainly use the thermal-healing center "Ilidža", then such length of stay is logical, since it is largely conditioned by the doctors' treatment requiring a longer stay i.e. by a specific type of therapy. The degree of utilization of accommodation establishments in Tuzla Canton in 2OII is I6.96 \% and far below the economic justification. Tourist destinations, hotels and other firms, should, in accordance with their offers and position in the market, seek an optimal relation of organized and individual tourism traffic so as to achieve the best possible utilization of capacities and financial effects.

Data on tourist traffic in TC shows that tourism is still an important economic sector in the region, which means that it deserves more attention from the cantonal authorities and represents a good prospect for the development of the Canton. The special role of tourism is that it affects the utilization of natural and anthropogenic resources in tourism development. Furthermore, it also affects the utilization of natural and economically indifferent resources for economically useful goods and the inclusion of non-economic activities in the economic cycle, i.e. the economic process (Festić, 1986:2I).

The natural and geographic richness and cultural heritage are spread over the entire area of TC. Thus, the area recorded 32 sites of extremely valuable natural resources (Group of authors, 200I: 59-67). An important part of resources of the natural heritage is, by its nature, of hydrological character: natural and artificial lakes, thermal and mineral springs, spring waters - individual and collective, and attractive waterways.

TC is a destination with rich cultural and historical values, which is the basis for the development of the tourism industry, a place where remarkable economic and other results have been achieved for decades. Also considered to be the cultural and historical heritage of TC are objects and the remains of various civilizations and societies that have remained in the area from prehistoric times to the present day. This is a broad spectrum of monumental inventory that belongs to the cultural milieu of various ethnic and religious systems of value left in this area by a number of civilizations: the Illyrians, Celts, Romans, Slavs, the Byzantine Empire, the Ottoman Empire and the Austro-Hungarian Empire. Owing primarily to its favorable geographical position, but also to its turbulent past, TC is also rich with numerous monuments (38I) (Group of authors, 200I:4I-42).

\section{Attitudes of cantonal authorities regarding tourism development}

TC tourism is not on a satisfactory level, which is particularly as a consequence of the lack of adequate business activities, stakeholder connectivity, insufficient use of information technologies and sustainable development concept. The current state of tourism infrastructure in Tuzla Can- 
ton to a higher degree is not in accordance with the requirements of foreign tourist demands, which is what the whole receptive market of Bosnia and Herzegovina aspires to. Travel experience of tourists from developed countries has, for a long time, been based on an active vacation rich with a variety of events. In order to achieve the aforementioned, it is necessary to apply modern forms of business, consumer access and information technologies. The current structure of the accommodation establishments is not yet fully adequate, in the sense that it does not reflect the specific requirements of modern tourism. This should be emphasized because the presented "rural household" does not include that which should be included by tourist standards, but it is instead a reflection of the legislation and generally refers to objects located in the vicinity of Lake Modrac which provide exclusive accommodation services. On the other hand, in the last two years, the level and quality of accommodation establishments, as well as the level and quality of their services, has significantly improved and is increasingly approaching the established European standards, especially when it comes to facilities such as "hotels" and "motels". At the same time it was found that there has been a significant improvement in the quality of stay in accommodation establishments, which was achieved by a significant increase in usable space available to the guests staying in these establishments (Information, 2OI2:5).

Tuzla Canton strives to become a developed inland tourism destination whose development is based on the sustainable use of natural and cultural resources and on medium and small entrepreneurship that will ensure the economic development of the Canton and create an attractive environment for investment, rest and recreation. The development of entrepreneurship in tourism is in its infancy and therefore it is necessary to influence on its development. Tourism Development Strategy in Tuzla Canton, published by the Ministry of Trade, Tourism and Transport of TC in 2000, indicates to the possibility of increased tourist traffic.

Due to the fact that Bosnia and Herzegovina has not yet been "discovered", many foreign tourists are an important target group to be influenced on by active marketing, for which increased and adequately structured investments in promotional activity are needed. Countries that seek to attract foreign tourists must have a big responsibility to their sensitivity regarding the promotion of tourist destinations.

In order to accelerate the development of tourism the following steps should be taken:

- creating an attractive environment;

- improvement of tourist infrastructure, especially in the domain of health, winter and agro-tourism; and

- the diversity of tourist attractions and provide better support services (Hodzic, 2005:I2)

Because of the existing natural resources and capacities, Tuzla Canton even has a special potential for the development of some tourism sectors such as health, winter and agro-tourism. Currently the tourism sector is faced with many problems such as the lack of a developed business environment, insufficient promotion of tourist activities, the lack of an appropriate institutional framework, etc., but the most important problems are those that are directly related to the infrastructure: unrenewed and uncompleted tourist facilities; poor quality of access infrastructure; unrenewed ecological and sanitary systems; unrenewed urban areas (Hodzic, 2005:7-I6).

In order to make a strong regional tourism sector, the Regional Plan for the area of Tuzla Canton from 2005 to $2 \mathrm{O} 25$ proposes undertaking the following activities:

- rehabilitation, improvement and development of tourist facilities including the domain of sport and recreation; 
- improving the quality of the tourism offer by improving, rehabilitating and further developing access infrastructure (roads - including bridges, railways, infrastructure for waterways transport) in areas with proven tourist attractiveness;

- ecological rehabilitation and renovation of public areas of high tourism value such as lakes, public parks, surrounding attractive destinations of proven value, etc.;

- rehabilitation of urban areas of high tourism value, including repairing streets in functional resorts/spas with a proven tourist attractiveness, rehabilitation of historic centers and pedestrian zones in cities with historical and cultural attractions.

In the process of undertaking the abovementioned activities, it is necessary to focus on areas of significant tourist interest, in the vicinity of the renowned tourist attractions or recognized tourist resorts of national and regional importance. Taking into account that some of these problems are the subject of other priorities and measures, these steps should concentrate on providing direct assistance to the rehabilitation, improvement and development of tourist capacities. This measure can be accomplished with the following project ideas:

- revitalization of ski centers;

- feasibility study for the renovation of the spas Terme (Gračanica), Toplice (Živinice) and Ilidža (Gradačac); and

- improving the structure of hunting and fishing tourism.

Expected results of these measures are:

- increased tourism activity;

- increased revenue from tourism; and

- creating a better tourist environment.

This measure can be implemented through the following project ideas: development, capacity building and networking of local travel agencies in the region, promotion of tourist attractions, supporting the development of rural tourism, mapping of mineral and thermal waters and their capacities, marketing promotion of health tourism activities, winter and agro-tourism, interregional cooperation in the field of tourism in Bosnia and Herzegovina and abroad, supporting the development of river and lake sports, the introduction of new and development of existing services in tourism and aiding the development of traditional crafts and cottage industries (Spatial plan, 2006:392-397 ).

\section{The attitudes of employees in accommodation establishments on tourism development}

The gender and age structure of the respondents was quite uniform with no larger fluctuations. The educational structure was favorable, 87.5 of respondents have secondary education, and the same number of them was of tourism and catering profession. Answers to the questions were provided by receptionists, and only in one establishment the chief accountant was the respondent.

In accordance with the type of accommodation the following participation was obtained: four of them are both resort and businesses, two are exclusively a resort, and two are all resort, business, sports and recreational facilities. All are in business throughout the entire year.

Answers to the question regarding the determining factor for a tourist in choosing a tour package in TC as a destination, both for domestic and foreign tourists, were almost all iden- 
Table 2. The distribution of frequencies for the variable: What is, in your opinion, the determining factor for tourists in choosing a travel arrangement in Tuzla Canton as a destination?

\begin{tabular}{|c|c|c|c|c|c|c|c|c|c|c|c|}
\hline \multicolumn{12}{|c|}{$\begin{array}{l}\text { Evaluation of the perception of tourists } \\
(1-\text { not crucial at all, } 2 \text { - has a minor influence on the selection, } 3 \text { - partially influences the selection, } 4 \text { - affects the selection, } \\
5 \text { - is crucial) }\end{array}$} \\
\hline Domestic tourists & 1 & 2 & 3 & 4 & 5 & Foreign tourists & 1 & 2 & 3 & 4 & 5 \\
\hline Arrangement price (reasonable) & - & - & - & 1 & 7 & Arrangement price (reasonable) & - & - & 2 & 6 & - \\
\hline Existing agency offer & - & - & 1 & - & 7 & Existing agency offer & - & - & - & 1 & 7 \\
\hline Destination (location) & - & - & - & - & 8 & Destination (location) & - & - & - & - & 8 \\
\hline $\begin{array}{l}\text { The basic product (the form of } \\
\text { tourism, services) }\end{array}$ & - & - & - & 1 & 7 & $\begin{array}{l}\text { The basic product (the form of } \\
\text { tourism, services) }\end{array}$ & - & - & - & - & 8 \\
\hline Accommodation & - & - & - & 1 & 7 & Accommodation & - & - & - & - & 8 \\
\hline $\begin{array}{l}\text { Complementary activities (sport, } \\
\text { culture, music...) }\end{array}$ & - & - & - & 2 & 6 & $\begin{array}{l}\text { Complementary activities (sport, } \\
\text { culture, music...) }\end{array}$ & - & - & - & - & 8 \\
\hline $\begin{array}{l}\text { Recommendation by an agent, } \\
\text { friend... }\end{array}$ & - & - & 1 & 4 & 3 & $\begin{array}{l}\text { Recommendation by an agent, } \\
\text { friend... }\end{array}$ & - & - & 1 & 4 & 3 \\
\hline
\end{tabular}

tical. For domestic tourists the price of the arrangement is a determining factor, while for foreign tourists this is not the case. The existing offer of the agency has almost the same great significance for both groups of tourists. The same applies to the destination (locality). The main product (tourism form, services), accommodation, complementary activities (sports, culture, music...) are crucial for foreign tourists, while domestic tourists consider them somewhat less important. A recommendation from an agent or a friend is of the same importance for both domestic and foreign tourists, i.e. it has a positive impact on the tourists when choosing a tour package in Tuzla Canton as a destination (Table 2).

Responses to the question of assessing the tourist's motives for travelling to (coming to) TC as a destination, were quite uniform, nearly identical for both domestic and foreign tourists. All factors are an extremely present motive for travelling for both groups of tourists. Foreign tourists, according to the employees of accommodation establishments, consider complementary activities (sports, culture, music,...) more important in comparison to domestic tourists. The reason for this is that foreign tourists, in their opinion, are more demanding in comparison to domestic tourists (Table 3).

When asked to characterize (assess) the value factors of the tourist offer of Tuzla Canton, responses provided for both domestic and foreign tourists were the same, except regarding the image. The destination image was assessed quite badly by both domestic and foreign tourists, with a more negative attitude from foreign than from domestic tourists. The existing infra and superstructure was also poorly assessed. On the other hand, availability and information system (quality and quantity of tourist information) were deemed to be good by both domestic and foreign tourists. Accommodating offer (equipment, content, capacity...), complementary activities (sports, cultural events, etc.), personnel (adequate by expertise) were similarly evaluated by both domestic and foreign tourists. These assessments indicate that these components should be worked hard on in order to create a better image of TC as a tourist region, i.e. that those working in the industry are aware of the insufficient quality and quantity of the aforementioned segments (Table 4).

When asked about what should be changed (corrected) in terms of accommodation establishments, it was noted that it is necessary to modernize the facilities and businesses. Furthermore, also mentioned were introduction of new content and better quality of service, since these represents the basis for tourism industry development in a region. 
Table 3. The distribution of frequencies for the variable: How would you assess tourists' motives for travelling to (coming to) Tuzla Canton as a destination?

\begin{tabular}{|c|c|c|c|c|c|c|c|c|c|c|c|}
\hline \multicolumn{12}{|c|}{$\begin{array}{l}\text { Factors - Perception of tourists } \\
1 \text { - motive completely absent, } \ldots 5 \text {-motive exceptionally present }\end{array}$} \\
\hline Domestic tourists & 1 & 2 & 3 & 4 & 5 & Foreign tourists & 1 & 2 & 3 & 4 & 5 \\
\hline Enjoyment & - & - & - & - & 8 & Enjoyment & - & - & - & - & 8 \\
\hline New experience & - & - & - & - & 8 & New experience & - & - & - & - & 8 \\
\hline New knowledge & - & - & - & - & 8 & New knowledge & - & - & - & - & 8 \\
\hline Change in everyday life & - & - & - & - & 8 & Change in everyday life & - & - & - & - & 8 \\
\hline Price (reasonable) & - & - & - & 1 & 7 & Price (reasonable) & - & - & - & 8 & - \\
\hline Value for money* & - & - & - & - & 8 & Value for money * & - & - & - & - & 8 \\
\hline Security (safety) & - & - & - & - & 8 & Security (safety) & - & - & - & - & 8 \\
\hline Reliability & - & - & - & - & 8 & Reliability & - & - & - & - & 8 \\
\hline People (hosts) & - & - & - & - & 8 & People (hosts) & - & - & - & - & 8 \\
\hline Locality & - & - & - & - & 8 & Locality & - & - & - & - & 8 \\
\hline Service & - & - & - & - & 8 & Service & - & - & - & - & 8 \\
\hline Complementary activities & - & - & & 2 & 6 & Complementary activities & - & - & - & - & 8 \\
\hline $\begin{array}{l}\text { That I will get what I want (Expe- } \\
\text { rience, service, fun...) }\end{array}$ & - & - & - & - & 8 & $\begin{array}{l}\text { That I will get what I want (Expe- } \\
\text { rience, service, fun...) }\end{array}$ & - & - & - & - & 8 \\
\hline
\end{tabular}

Table 4. The distribution of frequencies for the variable: How would you characterize (assess) value factors of the tourist offer of Tuzla Canton?

$\begin{aligned} & \text { Evaluation of the perception of tourists - your experience } \\
& \text { (1- very bad, ... 5- very good) }\end{aligned}$
\begin{tabular}{|l|c|c|c|c|c|l|l|c|c|c|c|}
\hline Domestic tourists & 1 & 2 & 3 & 4 & 5 & Foreign tourists & 1 & 2 & 3 & 4 & 5 \\
\hline Destination image & - & 1 & 7 & - & - & Destination image & 1 & 3 & 4 & - & - \\
\hline $\begin{array}{l}\text { Existing infrastructure and super- } \\
\text { structure }\end{array}$ & - & 2 & 6 & - & - & $\begin{array}{l}\text { Existing infrastructure and super- } \\
\text { structure }\end{array}$ & - & 2 & 6 & - & - \\
\hline $\begin{array}{l}\text { Availability and system infor- } \\
\text { mation }\end{array}$ & - & - & 7 & 1 & - & $\begin{array}{l}\text { Availability and system infor- } \\
\text { mation }\end{array}$ & - & - & 7 & 1 & - \\
\hline $\begin{array}{l}\text { Accommodation offer (equip- } \\
\text { ment, content, capacity...) }\end{array}$ & - & 2 & 5 & 1 & - & $\begin{array}{l}\text { Accommodation offer (equip- } \\
\text { ment, content, capacity...) }\end{array}$ & - & 2 & 5 & 1 & - \\
\hline $\begin{array}{l}\text { Complementary activities } \\
\text { (sports, cultural events, etc) }\end{array}$ & 1 & 3 & 4 & - & - & $\begin{array}{l}\text { Complementary activities } \\
\text { (sports, cultural events, etc) }\end{array}$ & 1 & 3 & 4 & - & - \\
\hline Staff (adequate by expertise) & - & 1 & 6 & 1 & - & Staff (adequate by expertise) & - & 1 & 6 & 1 & - \\
\hline
\end{tabular}

Table 5. The distribution of frequencies for the variable: competitiveness (domestic tourists)

\begin{tabular}{|l|r|r|}
\hline Activities & Numerical status & $\%$ \\
\hline Lower prices & 1 & 12.5 \\
\hline Lower prices, but also a better service & 2 & 25.0 \\
\hline Affordable prices & 3 & 37.5 \\
\hline Affordable prices, but also a better service & 2 & 25.0 \\
\hline Total & 8 & 100.0 \\
\hline
\end{tabular}


Table 6. The distribution of frequencies for the variable: competitiveness (from abroad)

\begin{tabular}{|l|r|r|}
\hline Activities & Numerical status & 1 \\
\hline Quality & 12.5 \\
\hline The quality of the offer, accommodation and service & 2 & 25.0 \\
\hline Quality in all segments and a rich offer & 1 & 12.5 \\
\hline Raise the quality in every segment & 2 & 1 \\
\hline Raise the quality in every segment because foreign tourists are more demanding & 1 & 12.5 \\
\hline $\begin{array}{l}\text { Foreign tourists are more demanding, therefore the quality of service, accommoda- } \\
\text { tion and offer should be at the top level }\end{array}$ & 12.5 \\
\hline Total & 8 & 100.0 \\
\hline
\end{tabular}

When inquired about what TC should base its competitive advantage on in terms of tourists (type of accommodation establishment, service, price, quality, origin of tourists ...), employees in accommodation establishments found that for domestic tourists affordable prices and better service were the basis for competitive advantage of TC, while for foreign tourists raising the quality of tourism services was a major factor TC should base its competitive advantage on (Tables 5 and 6).

\section{Attitudes of employees in travel agencies on tourism development}

The aim of this study is to examine the opinion of travel agencies as providers of tourist services on the further development of tourism in Tuzla Canton, since they too are one of the crucial factors in the development of tourism and attracting tourists.

Once again, throughout the research, there were no annulled questionnaires or unanswered questions. The gender structure of the surveyed was uniform, while the age structure showed that younger staff was more dominant. The educational structure was also very good, since high and higher education was more prominent and most employed had obtained their college degrees in the field of tourism and economics.

It is interesting to point out that everyone believed that promotion should be based on the media, with one respondent even listing the catalogs, while only one respondent listed the Internet. This response indicates that it is believed that the media (mainly TV and print) is still the most watched and most reliable in selling tourism products at the local level in Bosnia and Herzegovina. Here we come to the assumption that agencies base their business mainly on local population as a target group of potential consumers. It should, of course, be added that there is a lack of computer literacy among the older population in Bosnia and Herzegovina, but also in neighboring countries. This is why travel agencies choose public media as the safest method of promotion. All agencies responded that they base their offers on travelling within the borders of the country, but outside as well.

When inquired about the dominant forms of the Canton tourism found in the offers provided by the agencies, all respondents decided upon a different primary form. It was interesting that in the first place no one mentioned industrial heritage, shopping tour, adventure travel, rural tourism, or New Year's Eve celebration. Located on the first place were offers such as winter vacations, city tourism, excursions, spas and business tourism.

When asked whether foreign tourists in their home countries may use the agency's web site to find the necessary information about the tourist offer of Tuzla Canton, all respondents answered affirmatively, which indicated that travel agencies do understand the role and importance of global electronic resources in tourism activities. 
Table 7. The distribution of frequencies for the variable: What is, in your opinion, the determining factor for tourists in choosing a travel arrangement in Tuzla Canton as a destination?

\begin{tabular}{|c|c|c|c|c|c|c|c|c|c|c|c|}
\hline \multicolumn{12}{|c|}{$\begin{array}{l}\text { Evaluation of the perception of tourists: } \\
(1-\text { not crucial at all, } 2 \text { - has a minor influence on the selection, } 3 \text { - partially influences the selection, } 4 \text {-affects the selection, } \\
5 \text { - is crucial) }\end{array}$} \\
\hline Domestic tourists & 1 & 2 & 3 & 4 & 5 & Foreign tourists & 1 & 2 & 3 & 4 & 5 \\
\hline Arrangement price (reasonable) & - & 1 & - & - & 4 & Arrangement price (reasonable) & 4 & - & 1 & - & - \\
\hline Value for money* & - & 1 & - & 1 & 3 & Value for money * & 1 & - & 2 & - & 2 \\
\hline Existing agency offer & - & - & - & 1 & 4 & Existing agency offer & - & - & - & 1 & 4 \\
\hline Destination (location) & - & - & 2 & - & 3 & Destination (location) & - & - & - & 2 & 3 \\
\hline $\begin{array}{l}\text { The basic product (the form of } \\
\text { tourism, services) }\end{array}$ & - & - & 2 & 1 & 2 & $\begin{array}{l}\text { The basic product (the form of } \\
\text { tourism, services) }\end{array}$ & 1 & - & 3 & 1 & 1 \\
\hline Accommodation & - & - & 2 & 2 & 1 & Accommodation & 1 & - & 2 & 1 & 1 \\
\hline $\begin{array}{l}\text { Complementary activities (sport, } \\
\text { culture, music...) }\end{array}$ & - & 1 & 2 & 1 & 1 & $\begin{array}{l}\text { Complementary activities (sport, } \\
\text { culture, music...) }\end{array}$ & 1 & - & 3 & 1 & 1 \\
\hline $\begin{array}{l}\text { Recommendation by an agent, } \\
\text { friend... }\end{array}$ & - & - & - & - & 5 & $\begin{array}{l}\text { Recommendation by an agent, } \\
\text { friend... }\end{array}$ & - & - & 1 & 1 & 3 \\
\hline
\end{tabular}

* The obtained package $f$ value or the price paid

When asked what is the determining factor for a tourist in choosing a tourist package in TC as a destination, responses for domestic and foreign tourists were different. Price arrangements with domestic tourists, according to travel agents, was the most critical issue, while this had no importance whatsoever for foreign tourists. Value for money, i.e. the resulting package value for the price paid had almost the same importance and with domestic and with foreign tourists. The same applies to the existing offer from the agencies. Foreign tourists gave a slight advantage to destination (location) than domestic tourists. The main product of (the form of tourism, services), accommodation, complementary activities (sports, culture, music...) have approximately the same significance for both domestic and foreign tourists. A recommendation by an agent or a friend was crucial for domestic tourists, while for foreign tourists this bears little significance. The reason for this is that foreign tourists get information about TC tours by other means (mainly Internet presentations) (Table 7).

When asked to assess tourists' motives for choosing TC as a destination, employees in travel agencies answers answered in almost the same way for both domestic and foreign tourists. Enjoyment, both for domestic and foreign tourists, is a very crucial motive for traveling. Also a very existent motive for foreign tourists is new experiences, while this was less significant for domestic tourists. The same applies to new knowledge and a change in everyday life.

The price of the arrangement, in the opinion of employees in travel agencies, is presumably a very existent motive for travelling for domestic tourists, while foreign tourists pay little attention to this. Value for money for domestic tourists is a very high motive, while this is of no significance for foreign tourists. Security (safety) and reliability are an extremely present motive for traveling in foreign tourists, while these two components are of less importance for domestic tourists. People (hosts), locality, service, complementary activities, experience and fun are an extremely present motive for traveling for both domestic and foreign tourists (Table 8).

When asked to characterize (assess) value factors of the TC tourist offer, response of employees of travel agencies were the same for both domestic and foreign tourists. The image of the 
Table 8. The distribution of frequencies for the variable: How would you assess tourists' motives for choosing Tuzla Canton as a destination?

\begin{tabular}{|c|c|c|c|c|c|c|c|c|c|c|c|}
\hline \multicolumn{12}{|c|}{$\begin{array}{l}\text { Factors - Perception of tourists } \\
1 \text {-motive completely absent, } 5 \text {-motive exceptionally present }\end{array}$} \\
\hline Domestic tourists & 1 & 2 & 3 & 4 & 5 & Foreign tourists & 1 & 2 & 3 & 4 & 5 \\
\hline Enjoyment & - & - & - & 1 & 4 & Enjoyment & - & - & - & 2 & 3 \\
\hline New experience & - & - & 3 & 1 & 1 & New experience & - & - & - & - & 5 \\
\hline New knowledge & - & - & 3 & 1 & 1 & New knowledge & - & - & - & - & 5 \\
\hline Change in everyday life & - & - & 4 & - & 1 & Change in everyday life & - & - & - & & 5 \\
\hline Price (reasonable) & - & - & - & - & 5 & Price (reasonable) & 3 & - & - & 1 & 1 \\
\hline Value for money $*$ & - & - & - & 1 & 4 & Value for money * & 1 & 1 & 1 & 1 & 1 \\
\hline Security (safety) & - & - & 2 & 2 & 1 & Security (safety) & - & - & - & - & 5 \\
\hline Reliability & - & - & 1 & 2 & 2 & Reliability & - & - & - & - & 5 \\
\hline People (hosts) & - & - & - & 2 & 3 & People (hosts) & - & - & 1 & 1 & 3 \\
\hline Locality & - & - & 1 & 3 & 1 & Locality & - & - & - & 1 & 4 \\
\hline Service & - & - & - & 2 & 3 & Service & - & - & 1 & 1 & 3 \\
\hline Complementary activities & - & - & 3 & - & 2 & Complementary activities & - & - & - & 4 & 1 \\
\hline $\begin{array}{l}\text { That I will get what I want (Expe- } \\
\text { rience, service, fun...) }\end{array}$ & - & - & - & - & 5 & $\begin{array}{l}\text { That I will get what I want (Expe- } \\
\text { rience, service, fun...) }\end{array}$ & - & - & - & - & 5 \\
\hline
\end{tabular}

* Was the arrangement overpriced or not

destination was good both for domestic and foreign tourists. The existing infra and superstructure was bad for foreign tourists, while domestic tourists gave it a somewhat better evaluation. Availability and information system (quality and quantity of tourist information) were rather poor for domestic tourists, while foreign tourists gave them a better evaluation. Accommodating offer (equipment, content, capacity...), complementary activities (sports, cultural events, etc.), staff (adequate by expertise) were similarly evaluated by both domestic and foreign tourists. These evaluations indicate that these components should be worked hard on in order for TC to have a greater value as a tourist region and create a better image (Table 9).

Table 9. The distribution of frequencies for the variable: How would you characterize (assess) value factors of the tourist offer of Tuzla Canton?

Evaluation of the perception of tourists - your experience

(1-very bad, ... 5-very good)

\begin{tabular}{|l|c|c|c|c|c|l|c|c|c|c|c|}
\hline Domestic tourists & 1 & $\mathbf{2}$ & $\mathbf{3}$ & $\mathbf{4}$ & $\mathbf{5}$ & Foreign tourists & $\mathbf{1}$ & $\mathbf{2}$ & $\mathbf{3}$ & $\mathbf{4}$ & $\mathbf{5}$ \\
\hline Destination image & - & - & 2 & 1 & 2 & Destination image & - & - & 1 & 2 & 2 \\
\hline $\begin{array}{l}\text { Existing infrastructure and super- } \\
\text { structure }\end{array}$ & - & 1 & 3 & - & 1 & $\begin{array}{l}\text { Existing infrastructure and super- } \\
\text { structure }\end{array}$ & 1 & 2 & - & 1 & 1 \\
\hline $\begin{array}{l}\text { Availability and system infor- } \\
\text { mation (quality and quantity of } \\
\text { tourism information) }\end{array}$ & 1 & 1 & 1 & 2 & - & $\begin{array}{l}\text { Availability and system infor- } \\
\text { mation (quality and quantity of } \\
\text { tourism information) }\end{array}$ & - & 2 & - & 2 & 1 \\
\hline $\begin{array}{l}\text { Accommodation offer (equip- } \\
\text { ment, content, capacity...) }\end{array}$ & 1 & 1 & 1 & 2 & - & $\begin{array}{l}\text { Accommodation offer (equip- } \\
\text { ment, content, capacity...) }\end{array}$ & 1 & 1 & 1 & 1 & 1 \\
\hline $\begin{array}{l}\text { Complementary activities } \\
\text { (sports, cultural events, etc) }\end{array}$ & 1 & - & 2 & 2 & - & $\begin{array}{l}\text { Complementary activities } \\
\text { (sports, cultural events, etc) }\end{array}$ & 1 & 1 & - & 2 & 1 \\
\hline \begin{tabular}{l} 
Staff (adequate by expertise) \\
\hline
\end{tabular} & 2 & - & 2 & - & - & $\begin{array}{l}\text { Staff (adequate by expertise) } \\
\text { (ade }\end{array}$ & 1 & 1 & 1 & 1 & 1 \\
\hline
\end{tabular}




\section{Conclusion}

Answers provided by employees in travel agencies and TC hotels indicate that this destination has good potentials for the development of tourism, an economic branch that can strongly contribute to the overall economic growth. The geographical location, natural resources and anthropogeographical potentials show that there are favorable conditions for the development of the tourism industry in this canton. This region is rich in natural heritage and is one of the few regions that, for a relatively small area, has such a diverse and well-preserved natural environment, as well as numerous cultural heritage. However, TC tourism is not on a satisfactory level, which is a direct consequence of the lack of adequate business activities, stakeholder connectivity, insufficient use of information technologies and the concept of sustainable development.

In order to improve tourism in the area of Tuzla Canton, it is necessary to modernize the facilities and businesses. Also mentioned is the introduction of new content and better service quality, since this is basic for the development of the tourism industry in a region. It was also pointed out that affordable prices and higher quality services were the basis of competitive advantage of the Tuzla Canton. Finally, respondents believe that foreign tourists consider increasing the quality of tourism services a major factor Tuzla Canton should base its competitive advantage on. It can be assumed that improving the quality of services will positively influence on the satisfaction of tourists, which will result in increased sales and economic effects. The key to providing quality service is understanding and fulfilling tourists' expectations, which is ultimately the goal of every tourist destination, since doing so will attract and keep tourists in this region and encourage them to come again.

Potentials and values are great and only a right and timely strategy over a relatively short period of time can put them in the function of a modern and developed tourism, which is what TC strives for.

Research results can help tourist destination management, in this case, TC, but also all segments of the TC tourism industry to improve their offer, as well as communication with potential tourism markets.

\section{References}

Bakic, O. (2000). Management of tourist destination, Faculty of Economics, Belgrade. Hodzic, K. (2005). Tourism in regional economic development strategy Northeast Bosnia, Proceedings of the "Strategy for Economic Development of Tourism in Northeast Bosnia”, Tuzla, 5-I8.

Hodzic, K., Jašić, M. (2006). The economic development and tourism development in Tuzla Canton, Proceedings, Organization and development of tourism economy in Bosnia and Herzegovina and region of Northeast Bosnia, Tuzla, 74-88.

Ibreljić I., Kulenović, S. (2OO2). Possibilities for the development of tourism and catering in Tuzla Canton, Proceedings, No. 3, Faculty of Philosophy, University of Tuzla, I7-24.

Information about the situation in the field of tourism and catering and an overview of accommodation facilities and tourist traffic in Tuzla Canton, Ministry of Trade, Tourism and Transport, Tuzla, $2 \mathrm{OI} 2$. 
Kicošev, S. (2006). Planning the development of tourism and the basic approaches to tourism planning, Proceedings, Organization and development of tourism economy in Bosnia and Herzegovina and region of Northeast Bosnia, Tuzla, I49-I56.

Klapić, M. (2005).Some of the basic tendencies and characteristics of tourism development in the World and in the Tuzla Canton, Articles and materials for the cultural history of Eastern Bosnia, Book I8, Museum of Eastern Bosnia, Tuzla, 95-II5.

The Spatial Plan for the area of Tuzla Canton, 2005-2025, Ministry of Urban Planning and Environmental Tuzla Canton, Department of Urban Planning, Tuzla, 2006.

Simic, M. (2006). The importance of motivation in the tourism industry, Proceedings, Organization and development of tourism economy in Bosnia and Herzegovina and region of Northeast Bosnia, Tuzla, I57-I68.

The strategy economic development of tourism in Northeast Bosnia, Proceedings, Bosnia ARS, Tuzla 2005.

Strategic goals of tourism development in the area of Tuzla Canton until 2005, Tourism Sector, Ministry of Trade and Tourism of the Tuzla Canton, Tuzla, 2000.

Development Strategy in Tuzla Canton 2000-20I5, Phase B - Development Goals, University of Tuzla, 2000.

Development Strategy in Tuzla Canton from 2008 to 2OI3, The Institute of Economics, Sarajevo, 2008.

The strategy for tourism RS 2005-20I5 (first phase report), Ministry of Trade, Tourism and Services, Belgrade, 2005.

The strategy for tourism RS 2006-20I5 (second report - a strategic marketing plan), Ministry of Trade, Tourism and Services, Belgrade, 2006.

The strategy for tourism RS 2006-2OI5 (second report - the competitiveness plan), Ministry of Trade, Tourism and Services, Belgrade, 2006.

www.bhas.ba/index.php

www.fzs.ba/index.html 